\title{
ハードディスク潤滑剤の摩擦による 分解と表面の影響
}

一TOF-SIMS による分析一

\author{
沼田 俊充・森 誠之* \\ 独立行政法人 産業技術総合研究所機械システム研究部門 『 305-8564 茨城県つくば市並木 1 丁目 2-1 \\ *岩手大学工学部応用化学科 事 020-8551 岩手県盛岡市上田 4丁目 3-5
}

(2003 年 1 月 7 日受理)

\section{Friction Decomposition Reaction of Lubricant Oils Used for HDD and Chemical Effects of Slider Surfaces - Chemical Analysis by TOF-SIMS-}

Toshimitsu NumatA and Shigeyuki MORI ${ }^{*}$

\begin{abstract}
National Institute of Advanced Industrial Science and Technology, Research Institute of Mechanical Systems Engineering, 1-2-1 Namiki, Tsukuba, Ibaraki 305-8564

${ }^{*}$ Department of Applied Chemistry, Faculty of Engineering, Iwate University, 4-3-5 Ueda, Morioka, Iwate 020-8551
\end{abstract}

(Received January 7, 2003)

\begin{abstract}
Surface reactions on magnetic recording disks have been studied using our sliding test machine with ceramics slider under high vacuum conditions. Chemical changes of perfluoropolyether (PFPE) lubricant oils in the wear track were observed by time of flight secondary ion mass spectroscopy (TOF-SIMS). It was found that lubricant oils were decomposed even under very low loads less than $1 \mathrm{mN}$. The decomposition reaction was affected by the coating materials such as $\mathrm{Al}_{2} \mathrm{O}_{3}$, diamond like carbon (DLC), TiN or c-BN on the slider. Lubricant oils reacted also with $\mathrm{Al}_{2} \mathrm{O}_{3}$ and $\mathrm{TiN}$ slider surfaces. Metal (Al, Ti) fluorides were detected by TOF-SIMS in the sliding track after friction experiments. Material transfer is comfirmed by chemical wear of the slider material. The decomposition of lubricant molecules was initiated at the end group of molecules. On the other hand, DLC and c-BN sliders suppressed the decomposition of oil. With these materials, chemical wear was not observed. In conclusion, hard and chemically inert materials are suitable to develop a long-life head-disk interface.
\end{abstract}

\section{1. は じめに}

磁気ディスク装置, いわゆるハードディスクはコンピ ユータの記憶装置として重要な役割を果たしている。現 在, 磁気ディスク装置はコンピュータの高速化, 高機能 化に伴って急速に年率 100 パーセントもの割合で記録密 度の向上がなされており, 研究レベルでは $130 \mathrm{Gbit} / \mathrm{inch}^{2}$ に達している。

現在の磁気ディスク装置ではへッドはディスク上を浮

E-mail: t-numata@aist.go.jp
上したまま走行し, 情報の記録・再生を行っている。磁 気ディスクの記録密度を向上させるためには, ヘッドと ディスクの間隔（スペーシング）を短縮することが必要 であり，現行機種では $20 \mathrm{~nm}$ 以下の值である。しかし， スペーシングを短縮するとヘッドとディスクが接触する 確率が高くなり,ヘッドクラッシュが起こりやすくなる。 さらに，磁気ディスク装置の起動・停止時にはヘッド度 ディスクが接触するため摩擦・摩耗が問題となる。また, 将来導入が検討されているコンタクトレコーディング方 式では, 常時ディスクとヘッドが接触したまま情報の記 録・再生を行う。そのため, ヘッド-ディスク界面(HDI) 
のトライボロジ特性を向上させ，磁性層を保護する潤滑 油やカーボン膜の役割がますます重要になってきてい る( 3)。

以前から, HDI における潤滑油の分解反応に関して は化学的な見地より様々な研究が行われてきた ${ }^{49) 。 し ~}$ かし, 潤滑油の分解プロセスに関してはいまだはっきり とした答えは得られていない。

本稿では磁気ディスク HDI の信頼性や耐久性に強く 関係している保護膜, 特に潤滑油の分解反応について表 面科学の立場から検討した筆者らの研究例 ${ }^{10,11}$ を紹介し たい。

\section{2. 分子状薄膜の反応解析}

トライボロジ特性は分子状薄膜の化学構造に強く依存 し, 有機分子膜の構造解析は多くの分析方法を用いて行 われている ${ }^{12}$ 。高真空中で摩擦試験を行い, 分解反応に より発生する気体を質量分析法により検出する方法が多 く用いられている ${ }^{48)}$ こここでは, 摩擦面の化学変化を とらえるため, 飛行時間型 2 次イオン質量分析計 (TOFSIMS）を用いて表面分析を行った。

\section{1 ハードディスクの表面構造}

実験には Fig. 1 に示した 1.8 inch $(48$ mm) 磁気ディ スクを用いた。ディスクの構造は表面から潤滑油膜, DLC 保護膜, 磁性層, ガラス基板となっている。ディスク表 面の潤滑油は, 磁気ディスクで一般に用いられているパ ーフルオロポリエーテル (PFPE) 油 $\left(\mathrm{HOCH}_{2} \mathrm{CF}_{2}\left(\mathrm{C}_{2} \mathrm{~F}_{4} \mathrm{O}\right)_{\mathrm{n}}\right.$ $\left.\left(\mathrm{CF}_{2} \mathrm{O}\right)_{\mathrm{m}} \mathrm{CF}_{2} \mathrm{CH}_{2} \mathrm{OH}\right)$ で, 平均分子量は 2000 , 膜厚は $1 \mathrm{~nm}$ である。また, 潤滑油膜の下には, 水素添加 DLC 膜が $6 \mathrm{~nm}$ 成膜されている。

磁気ヘッドを想定したスライダには, シリコンウエハ を加工したビームヘッドを使用した。摩擦面の形状は 50 $\mu \mathrm{m}$ 角の平面である。本研究ではこのビームヘッドの摩 擦面に $\mathrm{Al}_{2} \mathrm{O}_{3}, \mathrm{TiN}$, ダイヤモンドライクカーボン (DLC), c-BN (立方晶窒化ホウ素) の 4 種類の材質を厚さ $0.5 \mu \mathrm{m}$ コーティングして使用し, 潤滑油の分解に対するスライ ダ材質の影響について検討した。なお，DLCはスパッ

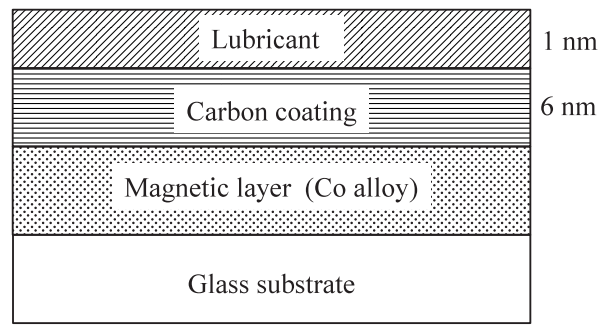

Fig. 1 Surface structure of magnetic disks.
タリングで成膜したものである。

\subsection{TOF-SIMS による分析}

本研究では, 摩擦による磁気ディスク表面の状態変化 を観察するために, TOF-SIMS の分析室に回転機構を組 み込んで摩擦試験を行った。

TOF-SIMS 内で摩擦試験を行うために, 専用のサンプ ルホルダを作成した。Fig. 2 にそのサンプルホルダの概 略図を示す。これは, 1.8 inch の磁気ディスクとスライ ダが取り付けられるようになっており, 同時に摩擦試験 機を兼ねている。スライダの押し付け荷重は, スライダ のシリコンビームのたわみ量によって制御される。

TOF-SIMS の分析室に回転機構を設け, 摩擦試験を行 った。具体的には所定の回数摩擦後, 回転を停止して摩 擦トラックの部分を分析した。分析終了後, 再びディス クを回転させて摩擦試験を続け, 所定の回数まで摩擦と 分析を繰り返した。

摩擦条件は, 荷重 $0.8 \mathrm{mN}$, 摩擦速度は約 $8 \mathrm{rpm}(0.01$ $\mathrm{m} / \mathrm{s}$ ) である。また, TOF-SIMS の測定条件は一次イオ ンに $\mathrm{Ga}^{+}$, 加速電圧 $15 \mathrm{kV}$, 二次イオンの極性は正, 分 析面積は $120 \times 120 \mu \mathrm{m}$ ，測定時間は $10 \mathrm{~min}$ である。

\section{3. 潤滑油の分解とスライダの化学摩耗}

Fig. 3 に摩擦回数 100 回における二次イオン $\mathrm{C}_{2} \mathrm{~F}_{4}{ }^{+}$に よるディスク表面のケミカルイメージを示す。このイメ ージでは明るいところほど二次イオン強度が強いことを 示している。中央部分で暗くなっており, そこが摩擦痕 であることがわかる。この結果より荷重 $0.8 \mathrm{mN}$ という 極低荷重下（実機の磁気ディスクでは $10 \mathrm{mN}$ 前後）に おいても摩擦によってディスク表面から潤滑油が消失し たことがわかった。

次に潤滑油の分解反応について検討するため, 摩擦痕 内部の各フラグメント強度を摩摖前の強度で規格化し,

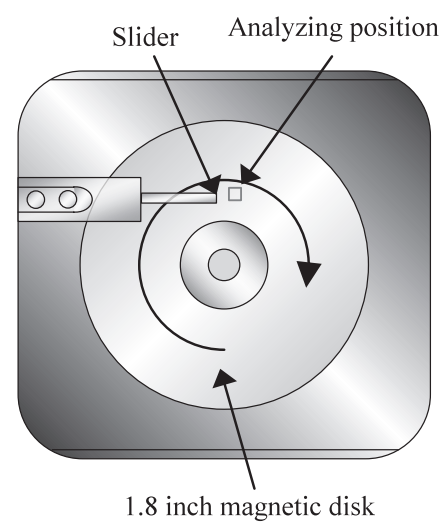

Fig. 2 Tribotester for TOF-SIMS. 
相対強度の摩擦回数に伴う変化を調べた。その結果を Fig. 4 に示す。この結果から, $\mathrm{C}_{2} \mathrm{~F}_{4}{ }^{+}$や $\mathrm{C}_{2} \mathrm{~F}_{4} \mathrm{O}^{+}$の主鎖に 由来するフラグメントでは摩擦回数が多くなるにしたが って相対強度が徐々に減少することがわかる。しかし,

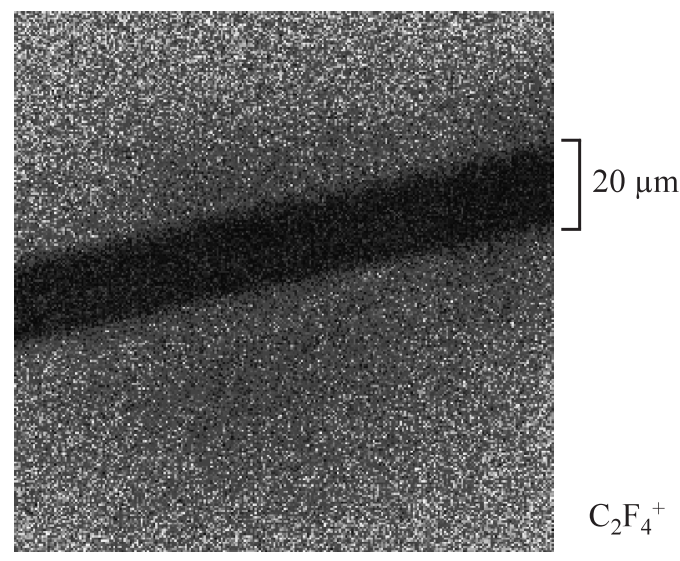

Fig. 3 Chemical image by TOF-SIMS. Slider: $\mathrm{Al}_{2} \mathrm{O}_{3}$, Load: $0.8 \mathrm{mN}$, Number of sliding: 100 .

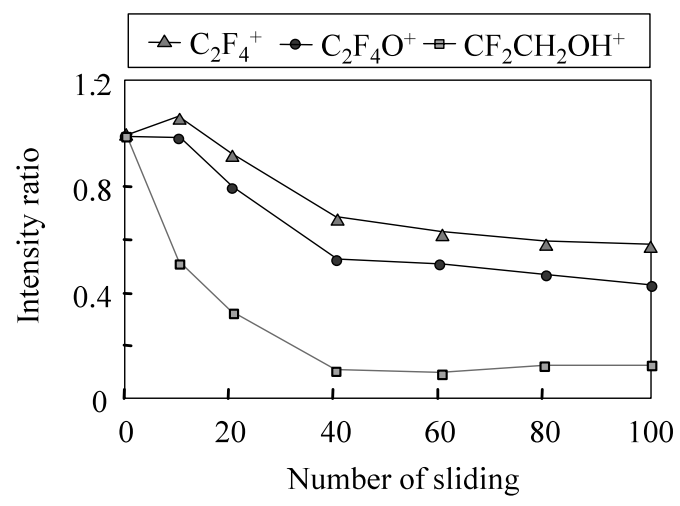

Fig. 4 Disappearance of the lubricant by friction.
潤滑油の末端基に由来するフラグメント $\mathrm{CF}_{2} \mathrm{CH}_{2} \mathrm{OH}^{+}$は 摩擦初期に相対強度が急激に減少しており, これは他の フラグメントとの傾向とは一致しない。このことは, 潤 滑油の化学的変質を意味している。言いかえれば，潤滑 油の末端基部分が摩擦初期から反応していることを示し ている。

Fig. 5 に摩擦回数 100 回におけるディスク表面のマス スペクトルを示す。このスペクトルは摩擦痕の内部の值 から外部の值を差し引いた差スペクトルである。この差 スペクトルから摩擦痕の内部では, 炭素が多く検出され ていることがわかる。これは摩擦によって摩擦トラック から潤滑油が失われ，下地の DLC 膜が露出したためと 考えられる。

さらに摩擦痕の内部には $\mathrm{Al}$ が多く存在することがわ かった。この実験において $\mathrm{Al}$ はスライダの $\mathrm{Al}_{2} \mathrm{O}_{3}$ にし か含まれていないため, 摩擦痕に存在する $\mathrm{Al}$ はスライ ダから移着してきたものである。本実験において荷重は $0.8 \mathrm{mN}$ （面圧約 $1 \mathrm{MPa}$ ） であり, また $\mathrm{Al}_{2} \mathrm{O}_{3}$ は硬い材質 であるため, スライダが物理的に破壊されたとは考えに くい。さらに, 質量数 46 付近に AlF のピークが存在す ることが確認された。したがって，スライダは物理的に 破壊され摩耗したのではなくPFPE 油と反応して化学摩 耗を起こしたと考えられる。

PFPE 油の熱分解反応についての研究例では, $\mathrm{Al}_{2} \mathrm{O}_{3}$ などの酸化物に PFPE のモデル化合物を吸着させて加熱 したところ, モデル化合物が分解し, その反応に酸化物 表面のルイス酸サイトと水酸基が重要な役割を果たして いるという報告がある ${ }^{13)}$ 。また, PFPE 油の分解に対す る $\mathrm{Al}_{2} \mathrm{O}_{3}$ の触媒的活性を報告した例もある ${ }^{14)}$ 。さらに, PFPE 油が分解したときに発生する気体に $\mathrm{CF}_{2} \mathrm{O}$ がある が15), $\mathrm{CF}_{2} \mathrm{O}$ は次式に示すように金属酸化物と反応し金 属フッ化物と, $\mathrm{CO}_{2}$ を生成する4)。

$\mathrm{nCF}_{2} \mathrm{O}+\mathrm{MO}_{\mathrm{n}} \rightarrow \mathrm{MF}_{2 \mathrm{n}}+\mathrm{nCO}_{2}$

このようにスライダと潤滑油が反応して $\mathrm{AlF}_{3}$ といっ

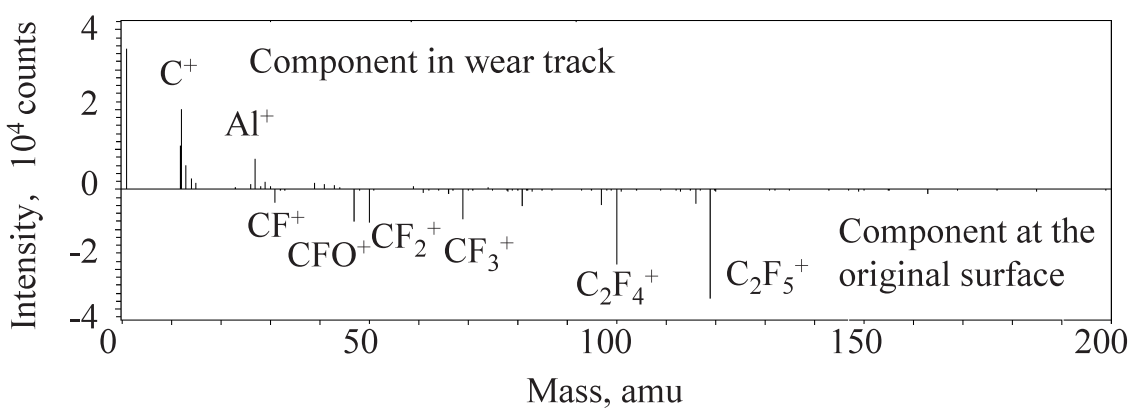

Fig. 5 Subtract mass spectra observed from disk surface. Slider: $\mathrm{Al}_{2} \mathrm{O}_{3}$, Load: $0.8 \mathrm{mN}$, Number of sliding: 100 . 


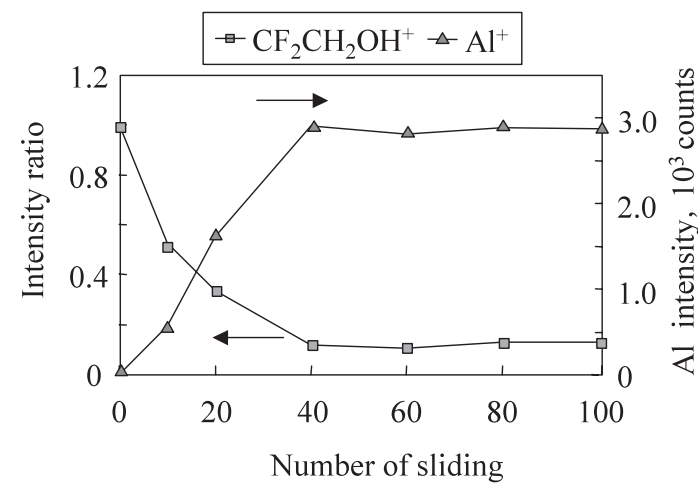

Fig. 6 Correlation between decomposition of the functional group and material transfer of $\mathrm{Al}$. Slider: $\mathrm{Al}_{2} \mathrm{O}_{3}$, Load: $0.8 \mathrm{mN}$.

た軟質のフッ化物を形成し，それが摩擦によって $\mathrm{Al}_{2} \mathrm{O}_{3}$ が化学摩耗を起こしディスクに移着したと考えられる。

そこで, 潤滑油の変質と $\mathrm{Al}$ の移着の間に相関関係に ついて検討した。この実験では摩擦初期に注目したので, 摩擦回数 10 回ごとに 100 回まで分析を行った。Fig. 6 に摩擦回数に対する末端基の減少と $\mathrm{Al}$ の移着の様子を 示す。この結果より明らかに末端基の減少に対応して, $\mathrm{Al}$ の移着量が増加していることがわかる。このことか ら, 潤滑油の分解は末端基から始まり, それに対応して $\mathrm{Al}_{2} \mathrm{O}_{3}$ が反応して $\mathrm{AlF}_{3}$ を形成し,この $\mathrm{AlF}_{3}$ は軟質なの で摩擦によってディスク側に移着したと考えられる。一 方, 分解により潤滑油が失われると, 下地の DLCが容 易に摩耗することが知られている ${ }^{16)}$ 。すなわち, $1 \mathrm{~nm}$ の潤滑油膜が硬質の DLC を摩耗から保護しているので ある。

\section{4. 潤滑油の分解に対するスライダ材質の影響}

潤滑油の分解反応に対するスライダ材質の影響につい て検討するために，4 種類のスライダを用いて摩擦試験 を行った。

潤滑油の消失量を定量的に評価するために, Fig. 3 に 示したイメージから摩擦痕のイオン強度断面図 (Fig. 7) を作成し, 図中に斜線で示したイオン強度損失面積を計 算した。その結果を Fig. 8 に示す。 $\mathrm{Al}_{2} \mathrm{O}_{3}, \mathrm{TiN}$ のスライ ダでは摩擦回数 400 回の段階ですでに潤滑油が消失して いたのに対して, c-BN と DLCのスライダを用いた場合 に潤滑油の消失量が少ないことがわかった。また, c-BN スライダの場合摩擦回数 1000 回でもほとんど潤滑油の 消失は進行していなかった。一方, DLC は摩擦回数 1000 回では潤滑油の消失量がかなり増えていた。この結果か ら, 潤滑油の消失量はスライダ材質に依存し, その序列

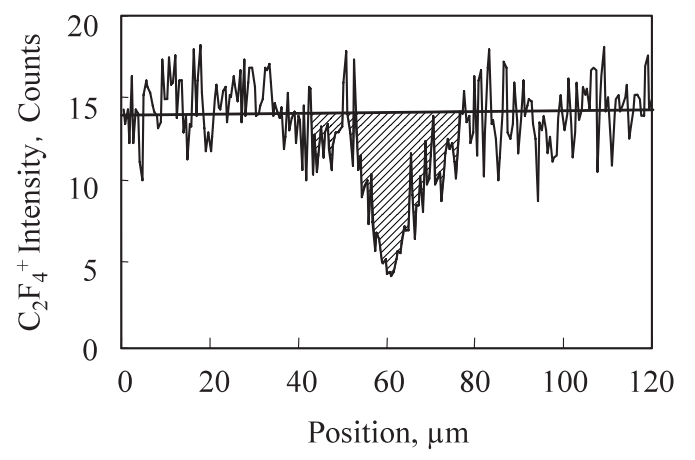

Fig. 7 Cross section of TOF-SIMS image. Number of sliding: 100, Slider: $\mathrm{Al}_{2} \mathrm{O}_{3}$.

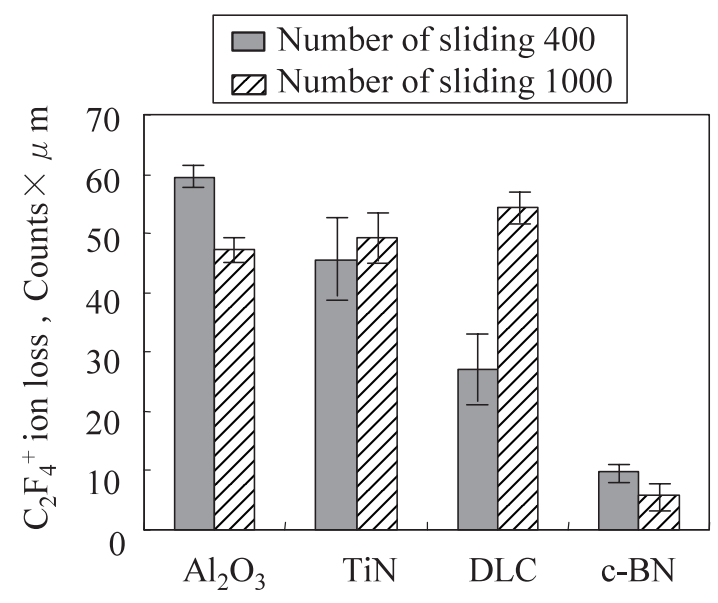

Fig. 8 Effect of slider materials on lubricant loss.

は, $\mathrm{Al}_{2} \mathrm{O}_{3}, \mathrm{TiN} \gg \mathrm{DLC}>\mathrm{c}-\mathrm{BN}$ であることがわかる。

さらにTiNのスライダにおいても質量数 46 付近に $\mathrm{Ti}$, 質量数 67 付近に $\mathrm{TiF}$ のピークが確認され, スライ ダ材質のディスクへの移着が認められた。一方, c-BN のスライダを用いて摩擦試験を行った場合には, スライ ダ材質の移着は確認できなかった。

Fig. 3 で, 潤滑油分子の主鎖と末端基の反応性の違い が示された。そこで, 潤滑油分子の末端基のフラグメン トイオン $\mathrm{CF}_{2} \mathrm{CH}_{2} \mathrm{OH}^{+}$と主鎖のフラグメントイオン $\mathrm{C}_{2} \mathrm{~F}_{4}{ }^{+}$ との相対強度の摩擦による変化を Fig. 9 に示す。 $\mathrm{Al}_{2} \mathrm{O}_{3}$ およびTiNのスライダを用いた場合には，この相対強 度が摩擦によって急激に減少しており, 潤滑油分子の未 端基が優先的に消失したことがわかる。これに対して, DLC, c-BN のスライダを用いた場合にはこの相対強度 はほとんど変化しておらず, 潤滑油分子の末端基の選択

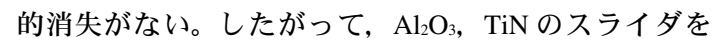
用いた場合には潤滑油が激しく劣化するが, DLC, c-BN 


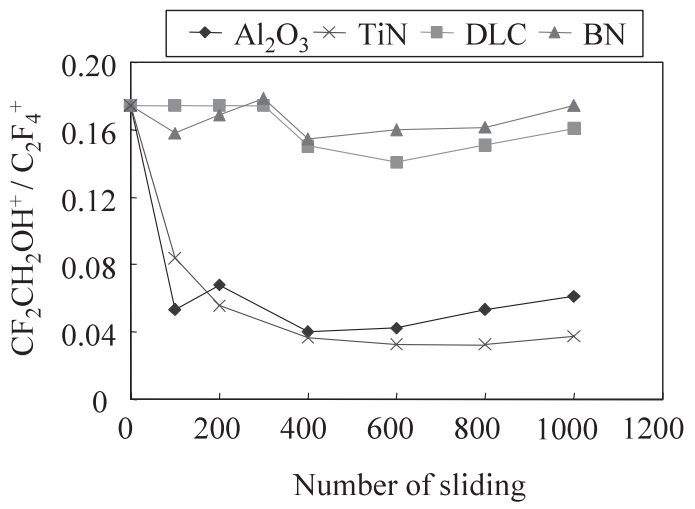

Fig. 9 Effect of slider materials on tribochemical decomposition. Load: $0.8 \mathrm{mN}$, Number of sliding: 1000 .

のスライダを用いた場合には潤滑油の摩擦耐久性が優れ るといえる。

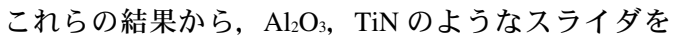
用いた場合には, 潤滑油とスライダ材質が反応して化学 摩耗を引き起こし, ディスクにスライダ材質が移着し, 潤滑油の分解を促進するため耐久性に劣る。 $\mathrm{Al}_{2} \mathrm{O}_{3}$ はル イス酸として作用するので PFPE 分子と反応し, 分解反 応を促進すると考えられる ${ }^{13,17}$ 。また，TiN も表面には $\mathrm{TiO}_{2}$ が存在すると考えられるので，これもルイス酸と して作用する ${ }^{13)}$ 。そのため, これらの材質は PFPE 分子 と反応しやすいと考えられる。また，摩擦により表面が 破壊されて生成する新生面は表面に欠陥を多く有してお り，化学的に活性である。特にセラミックスの新生面は dangling bond を有するため, フッ化炭素化合物とよく反

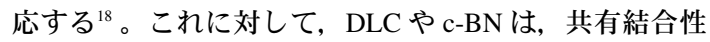
の物質で活性なルイス酸サイトを持たない。このため, これらの材質は潤滑油に対して不活性なので, 潤滑油の 分解を促進することは無く, 而久性に優れているといえ る。しかし，DLCにはラジカルサイトが残存するとい われており，さらに分解反応を抑制するには，これらの 活性サイトを除去すると効果があると予想される。

\section{5. と め}

以上の結果より, $0.8 \mathrm{mN}$ という極低荷重下において 摩擦により潤滑油の PFPE が消失することがわかった。

また, $\mathrm{Al}_{2} \mathrm{O}_{3}, \mathrm{TiN}$ をスライダに用いた場合には $\mathrm{Al}, \mathrm{Ti}$ がディスクに移着していることが確認された。これは, 潤滑油とスライダが反応して，これら $\mathrm{Al} ， \mathrm{Ti}$ のフッ化
物を形成し化学摩耗を起こしたためであると考えられ る。さらに, 潤滑油分子の末端基のみが特異的に減少し ていることから潤滑油の分解は未端基から起きているこ とが示唆された。

潤滑油の分解反応に対するスライダ材質の影響につい て検討したところ，DLC，c-BNをスライダ材質に用い た場合には，潤滑油の分解を抑制できることがわかった。 これらの材質はルイス酸として作用する $\mathrm{Al}_{2} \mathrm{O}_{3}$ や $\mathrm{TiN}$ と は異なり共有結合性の物質であるため, 潤滑油と反応し にくいと考えられる。

したがって潤滑油の分解を抑制し HDI の信頼性や耐 久性を向上するにはスライダと潤滑油の反応を阻止する ことが重要であり, 硬質保護膜には化学的に安定である ことも求められる。

\section{文献}

1) 森 誠之, 沼田俊充: トライボロジスト $\mathbf{4 3}, 388$ (1998).

2) B. Zhou, Y.-W. Chung, 川久保洋一(訳) : トライボ ロジスト 43, 382 (1998).

3) 沼田俊充, 森 誠之: 月刊トライボロジー 181, 34 (2002).

4) S. Mori, N. Onodera and M. Itoh: Wear 168, 85 (1993).

5) V.J. Novotony, X. Pan and C.S. Bhatia: J. Vac. Sci. Technol. A 12, 2879 (1994).

6) B.D. Strom and D.B. Bogy: Wear 168, 31 (1996).

7) B. Bhushan and Y. Cheng: J. Appl. Phys. 81, 5390 (1997).

8) X. Yun, D.B. Bogy and C.S. Bhatia: J. Tribol. 119, 437 (1997).

9) 雨宮哲夫, 吉野信行, 梅田芳男, 二瓶好正：日本応 用磁気学会誌 19, 50 (1995).

10）沼田俊充, 七尾英孝, 森 誠之：トライボロジスト 47, 400 (2002).

11）沼田俊充，七尾英孝，三宅正二郎，渡部修一，森 誠之：トライボロジスト 47, 406 (2002).

12) 大谷比呂子, 森 誠之: 応用物理 64, 1198 (1995).

13) P. Li, E. Lyth, D. Munro and L.M. Ng: Tribology Letters 4, 109 (1998).

14) W. Morales: Tribology Trans. 39, 148 (1996).

15) S. Mori and W. Morales: Wear 132, 111 (1989).

16）沼田俊充, 小野寺浩, 三宅芳彦, 森 誠之：トライ ボロジスト 4, 374 (1999).

17) P.H. Kasai, W.T. Tang and P. Wheeler: Appl. Surf. Sci. 51, 201 (1991).

18) $\mathrm{X} \mathrm{Wu}, \mathrm{P}$. Cong, H. Nanao, K. Kobayashi and S. Mori: Langmuir 18, 10122 (2002). 